\title{
Effects of Storytelling on Improving EFL Students' Critical Thinking and Reading Comprehension
}

\author{
Javed Sahibzada \\ Senior Teaching Assistant \\ English Language and Literature Department \\ Kandahar University \\ Kandahar, Afghanistan \\ E-mail: sahibzada.javed@gmail.com \\ Yar Mohammad Bahrami Ahmadzai \\ Associate Professor \\ English Language and Literature Department \\ Kabul University \\ Kabul, Afghanistan \\ E-mail: yarm.bahrami@gmail.com \\ Azadkhan Niaz \\ Teaching Assistant \\ English Language and Literature Department \\ Kabul University \\ Kabul, Afghanistan \\ E-mail: azadkhan.niaz@gmail.com \\ Susan Hussein Laftah \\ Assistance Lecturer \\ Department of English Language and Literature Department \\ Dhi Qar Education Directorate \\ Thi-Qar, Iraq \\ E-mail: samesoul.jan@gmail.com
}

Abstract

The purpose of this study is to find the effects of storytelling (ST) on improving critical thinking and reading comprehension of EFL students at Kandahar University. The design of the study was quasi-experimental with critical thinking and reading comprehension pre and posttests. Total 27 Afghan EFL students were selected based on their performance on Placement test. The participants of experimental group listened to their teacher telling the story. In order to find the improvement and different between these variables is significant the Paired Sample T-Test was administrated and the result indicates that there is significant improvement in post-tests in areas of reading comprehension and critical thinking in group of storytelling. However, improvement is higher in reading comprehension section than critical thinking.

Keywords: Critical Thinking, EFL, Reading Comprehension, Storytelling.

\section{Introduction}

As human being we all have somehow experiences of listening to other people telling or narrating us their own or other stories. Stories have been an attractive and interesting way of getting attentions. The long-life effects of our parents' stories still existed as unforgettable memories of our childhood. They were telling us different types of stories for various purposes such as; fairy tells to entertain us, bed time tales to make us sleep or in forms fables and parables to motivate us for positivity and avoid us from negative deeds. Stories are playing significant role in personality development of individual or groups and their impact shouldn't be ignored. The constructive parents' advices in the form stories, have always brought the aptitude and attitudinal change into the lives of children. Attempting to take advantage of the undeniable fun and enjoyment in stories, teachers try to include stories in different classroom activities. 
Storytelling is one of the effective ways of presenting a story and reading aloud is the second way. For different reasons, teacher may prefer one over the other. Abrahmsen (1998) has found that storytelling is a very important foundation of the teaching profession and it can be beneficial in improving students' speaking as well as listening skills. Sharing experiences through the device of storytelling enable individuals to build understanding between one another. Al-Mansour \& Al-Shorman (20I I) have found that listening to stories, read aloud helped the students developed sound listening habits and at the same time paved the way to promote comprehension through consistent exposure to the interesting and meaningful content of the stories. He found that reading story aloud has positive impact on language skills. Storytelling may increase students' language comprehension in quite remarkable ways. It can also provide moralistic lessons, long life learning and push the learners to be in touched with past experiences.

\section{I.I Definition of Terms}

Storytelling: Storytelling specifically refers to the presentation of a story without the presence of a picture book. Movements, sound effects, and the use of props often accompany the oral elements of the story presentation Gallets (2005).

Critical thinking is defined as the intellectually disciplined process of actively and skillfully applying, analyzing, synthesizing, and or evaluating information gathered from, or generated by, observation, experience, reflection, reasoning, or communication, as a guide to belief and action Saadati, Tarmizi \& Bayat (20I0).

Reading Comprehension: Meaning arrives because we are purposefully engaged in thinking while we read. It does not arrive because we have highlighted text or used sticky note or answered the comprehension worksheet Tovani (2000).

\section{I.3 Statement of Problem}

Most of the students enrolled in English language learning classes of Afghan context have difficulty in reading. Research conducted by Sahibzada, Saeedi \& Hussaini (2018) to find out the causes of poor language skills. Their findings indicated that $83 \%$ of the teachers are not happy about their students' language skills improvement. They have found that students had problems in language skills while entering EFL classes and after they have been taught for years, they still had problem in their foul language skills. However, they have more problem in their reading and listening comparing to speaking and writing.

There is a misconception among EFL teachers that telling the stories and reading aloud are only habits confined to the early stages, but they are in fact vital tools used to improve literacy and improve learning skills. Reading comprehension is not only problem in Afghan context but it also be found in different countries and various areas. For instance, those who are taking TOFEL or IELTS are complaining about their week performance in reading section. Since reading required much practice and extensive reading habits. Haycock \& Huang (200I) findings suggest that the half of all white seventeen-year old students, and about less than one-quarter of Latin seventeen years and less than one-fifth of African-American seventeen years old students can read at the level assessed by National assessment of educational progress.

As the important element of effective reading is linked to the positive interdependence of students on comprehension, improving critical thinking skills that are developed through storytelling and story reading. Through storytelling, one can improve speaking ability, listening skills and reading strategies because storytelling relies on both the listener and the teller. This strategy utilizes the social element of language. Researchers have found that literacy instruction is most effective when developed through social interaction and collaboration with others Dugan's (I997).

Through storytelling teachers engage learners actively in class participation. They also make learners to construct their own understanding, by building upon their previous knowledge. Promoting students' social instruction on meaningful tasks enhances learning. Finally, Storytelling offers unlimited opportunities for developing students' authentic awareness and respect for children with diverse language and cultural backgrounds.

On the other hand, impacts of storytelling on critical thinking and comprehension on adult learning needed to be comparatively studied with the intermediate learners is a gap exists to be tasted on students with different level, age and different context. It should be highlighted whether storytelling increase the students' comprehension and critical thinking. According to Eisner, as citied in Miller \& Pennycuff (2008) "The enduring outcomes of education are found in...the joy of the ride, not merely arriving at the destination." Miller \& Pennycuff (2008) further suggested that Eisner's vision will be embraced as teachers find ways to implement storytelling in the classroom and researchers continue to study the benefits of this pedagogical strategy on reading and writing achievement. Beside this, one cannot be a successful teacher using the same method in every context or every course. In order to cause learning, a teacher needs to adopt Eclecticism (efficient principles from different method).

\section{I.4 Objectives of the Study}

This study aims to compare the effectiveness of storytelling in improving reading comprehension and critical thinking on adult EFL learners. However, if there is difference existed in the effect of storytelling on reading comprehension and critical thinking such difference is significant or insignificant will be another main objective of this research. 


\section{I.5 Research Question}

- What is the effect of Storytelling on improving reading comprehension and critical thinking on EFL students?

- Is there any significant difference between in Storytelling with regards of improving critical thinking and reading comprehension among EFL students?

\section{I.6 Importance of the Study}

Institutions around the world are working to change their traditional classes which are more passive and teachers-centered where only teachers are carrying responsibilities on their shoulders. Consequently, it leads their graduates having poor performance in markets and lack of job ready skills. They are now shifting into modern approaches which are more active where students are responsible to carry work done by them and term teacher is no more in use and has been replaced to the term facilitator. One of the main responsibilities of a facilitator is to create a stress-free environment where students are enthusiastic for active engagement in the learning process and internalize it through constructivism. Thus, the facilitators in institutions should adopt the new teaching methodologies and adopt the new approaches used around the world to help their students bring changes into their lives. Using traditional methods and concepts cannot grantee the accomplishment of desired outcomes or to walk in clearly defined world of achievements.

The study will open a passage for storytelling to be consider as an important tool in language teaching. It will create positive attitudes in students towards extensive reading and developing dispositions like curiosity, playfulness, perseverance, confidence, resourcefulness, and risk-taking. Although it is famous around the world, but unlike the general awareness on the importance of reading books, the importance of verbal storytelling is not almost emphasized in Afghan culture. Yet, the stories make a great contribution to teaching techniques. Stories have been used as an effective tool for developing competence in language learning both in acquiring native language and learning foreign languages.

The educational value of story reading is widely accepted, especially compared to the acceptance accorded to storytelling. There is need for investigating the effect of storytelling. The reason adults read to children for the hope that reading exciting stories to children might help them in turning children in getting excited in learning in order to read books for themselves. Students are searching their memories for details of events they are orally presenting them and it will be easy for them to produce it as written form later National Council of Teachers of English (1992). They further suggest to develop cooperative class and instructive way, teacher and students should use storytelling to improve learning.

The study will provide teachers with effective teaching methods based on students' needs, interests, levels and desires. Storytelling is the only tool which can able us transcending into other people's lives and evokes feelings of empathy in a way that a story can become alive and mind changing experience for us. It will give chance to students to express their feelings and acquire the second language as their first language into natural process, because storytelling and reading is a kind of natural process. We are usually busy in storytelling as every day routine. We are telling our busy day's story at home and our commuting story to our colleagues and classmates. The study will encourage teachers to use storytelling as part of curriculum activities because of it has great effects on students learning outcome.

So, the analysis of it will pave a way to the curriculum designers and instructors to include it into their curriculums and specially the language instructors for enhancing the language ability. The current study will pave the way for adding storytelling as an important tool of learning for improvement of critical thinking and reading compression which are not only helpful for reading but also for all language skills.

\section{Literature Review}

The story storytelling, as important tools for the development of students' language ability, is widely accepted in the field of education and much of the study has been conducted in the effects of it on children and adult learning. The researchers have attempted in section of literature review to summarize the conducted studies on the effect of storytelling on learning of students in various geographical locations, scholars' different view regarding storytelling and comparative researches that investigate the effects of storytelling and story reading on learnings and literacy development.

\section{I Impacts of Storytelling}

Many researchers have investigated effects of storytelling on improvement literacy development through storytelling and also find it as tools for teaching and improving literary skills on various areas. Mello' (200I) has found through meta-analysis eight aspect regarding the use of storytelling as a pedagogical strategy through students' retellings, measures of fluency, and writing samples from the students. He has found with the use of pre and posttest interview that the literacy improves through storytelling in academic areas including vocabulary acquisition, fluency, recalling information writing skills, self-awareness cultural knowledge and imagery. In addition to that, Eisner as citied in Miller \& Pennycuff (2008) stated that with use of oral descriptive language, students' experience of literature is developed. As it provides opportunities to develop students' ability to increase in value and know the qualities conveyed in learning which in turn it develops their literacy skills in the classroom. According to Remenyi 
(2005) using storytelling as the medium of the performing arts is a key way of sharing knowledge among people as it makes participants to go to another setting and time place. Haven \& Ducey (2007) also have found that storytelling is an effective tool for developing early literacy and it helps reading comprehension skills of the students.

Besides that, storytelling is an effective means of developing students' literacy and reading comprehension researchers have found them as tools to improve various language skills. The studies by the studies by Millo (200I); Phillips (I999) suggested that storytelling is an effective way of developing reading comprehension and literacy skills of the students. Storytelling is a great way which bridge "cultural divides" providing different interpretations of the main story that teacher is telling. It assists children connect their previous experiences with larger world provided in the text and it promote reading comprehension in proper way of developing capacity of all children academically. Ta'amneh (2018) has also investigated effects of storytelling in development of reading comprehension skills of EFL students. He has found storytelling as an effective method for developing students' different language skills. He further discussed storytelling as a teaching activity, can attract the students in the teaching process and facilitates the learning process. He also acknowledged that students should be given stories for reading or telling those which are particularly close to their real-life contexts. He found out that storytelling by the EFL teachers should be promoted as it helps as an effective teaching technique in developing the students' reading comprehension.

Storytelling can be used as an effective strategy for students' comprehension, especially for the students having reading comprehension problem. To boost up comprehension, teachers can help students monitor their own understanding as they read. One common strategy teacher often use in a whole-class format is to think-aloud (Goudvis \& Harvey 2000).

Traditional method of using text for stories which is not helpful in all contexts and every level of learners. Method of storytelling and story reading is effective for the children in many ways and its various impacts had been researched. Stories have enormous potential to help students overcome barriers that may be interfering with their learning processes. It is necessary not to consider them only as a fun teaching device that helps the students to feel relax but they can be used as a means to improve the quality of learning in the classroom. Stories are highly motivating and can help develop positive attitudes towards the foreign language and language learning. They can create a desire to continue learning, raise the imagination, link fantasy and the imagination with the child's real-world Ellis \& Brewster (20I4, PI).

Apart from storytelling improved literacy, reading comprehension and its used as a tool for teaching various areas, researchers have also investigated how storytelling have contributed to the critical thinking, vocabulary development as Soleimani \& Akbari (2013) investigated the effect of storytelling on children's learning English vocabulary. As a result, they have recommended that storytelling is a method that is suitable to increase English vocabulary learning among children. Their study showed that student' vocabulary mastery increased accordingly.

Listening and speaking was the interested issue for the researchers. Miller \& Pennycuff (2008) concluded that storytelling is an effective method that combines the aesthetic ways of understanding instruction and developing the academic performance of learner in the areas of reading and writing. It also has the ability to promote the arts in education and motivate children to connect with their learning for pursuing lifelong literacy. Abrahmson (1998) has explained that storytelling is a very foundation of the teaching profession which can be beneficial in improving students' speaking as well as listening skills. Sharing of experiences through the device of storytelling enable individuals to build understanding between one another. In addition, Furlong (20I3) stated that storytelling is universal characteristic and it is important for everyone for their daily lives that helps in fostering commination. He further indicated that storytelling is effective tool for developing and creating communication in group of students which can elect classroom participation of reluctant reader/writers and disenchanted English students who have only see English class as a place of large novels with little discussion of stories are meaningful to them. Moreover, Straková, (20I I) wrote that storytelling belongs to language classroom as a valuable form of education and learning resource that enable and improve students' speaking skills. according to Gallets (2005), storytelling enables learners' speaking skills and it can be used as an intensive story reading to motivate adult students for reading in English in their spare time. Storytelling and story reading are the oldest form of education. Students are searching their memories for details of events they are orally presenting them and it will be easy for them to produce it as written form later National Council of Teachers of English (I992). They further indicated that to develop cooperative class and instructive way, teacher and students should use storytelling to improve learning. On the other hand, listening comprehension was also investigated by Al-Mansour \& Al-Shorman (20I I) who asserted that listening to stories, read aloud helped the students developed sound listening habits and at the same time paved the way to promote comprehension through consistent exposure to the interesting and meaningful content of the stories. He further found that reading story aloud has positive impact on language skills.

Storytelling improve writing and play major role in development of writing in different ways. Since Writing requires thinking and can be crossed through cognitive processes. Craig, Hull, Haggart, \& Crowder (200I); Eisner as citied in Miller $\&$ Pennycuff (2008). Since Writing requires thinking and can be crossed through cognitive processes. It is considered, the most complex skill because it goes through different stages i.e., prewriting writing and editing to reach its final product. As writing is an individual process which requires thinking strategies that allows individuals to express themselves competently in the other 
language. It is also a complex activity that requires a certain level of linguistic knowledge, writing conventions, vocabulary and grammar. Writing is a continuous process of thinking and organizing, rethinking, and reorganizing.

Alkaaf \& Al-Bulushi (2017) found out that storytelling as effective strategy that benefit teachers when they want to advance students' writing skills. They further stated that learners often find it difficult to process and organize written information and when writing stories, they cannot always retrieve the information required for the development of the story. Besides that, they proposed generating relevant ideas for their stories is another dimension which they may regard as challenging. They suggest and emphasized on this strategy for it works efficiently in language learning.

As children grow and their language develops, they use storytelling in their plays to imagine events and create world. Even when students become more engaged in reading and writing processes, teachers can continue to use storytelling as a powerful classroom instrument. Children can try out their ideas, and orally rehearse before they commit their ideas to paper, thus improving "the flow, fluency and feel of their writing" Cremin, Mottram, Collins, Powell \& Safford (2009). A study by Nicolini as citied in Miller \& Pennycuff (2008) report a high correlation between good readers and good writers, as well as poor readers and poor writers. They stated that even when students become more engaged in reading and writing processes, teachers can continue to use storytelling and story reading as a powerful classroom instrument.

Some researchers investigated the effects of storytelling on critical thinking. For instance, Belet \& Dala (2010) have conducted qualitative research on 53 the primary education pre-service teachers' opinions about the use of storytelling to develop the primary school students' critical reading skills. Their result indicated that 52 of the participants had positive opinions about the use of storytelling can develop critical reading skill. They also had positive opinions about the contribution of this method was well-suited with the skills explained in literature within the context of critical reading. The study further suggested that this method can develop the primary school students' prediction skill. Besides that, Chan (2019) acknowledges that storytelling enhances students' critical thinking and it allows them to explore their imaginations, practice their listening skills and experience new vocabulary as well as giving them the opportunity to spend quality time together. His study explained that storytelling is also useful for children to develop the ability to think critically; being able to interpret and reflect on information. He described that critical thinking skills are required in later school life, and also help with problem solving and forming opinions about various topics. Another study by Palmer, Harshbarger \& Koch (200I) who have investigated the effect of storytelling through observational method and have find out that storytelling is as a vehicle for expanding children's existing oral language and developing their literacy abilities. They further asserted that storytelling is rich in interaction process that facilitates imagination, creative thinking, language abilities, and cooperative learning. Through storytelling teachers engage learners actively in class participation. They also make learners construct their own understanding, by building upon their previous knowledge. Promoting students' social instruction on meaningful tasks enhances learning. Finally, Storytelling offers unlimited opportunities for developing students' authentic awareness and respect for children with diverse language and cultural backgrounds.

\subsection{Research on Effects of Storytelling and Story Reading}

In this part of literature, researchers have documented comparative studies which indicate effects of storytelling and story reaching in academic achievements of students in various areas. Sanaeifar (2018) investigated the effect of word exposure frequency through story reading and storytelling on learning collocations. He has found that the word exposure frequency through story reading and storytelling have statistically significant effect on collocation learning and also the story reading group performed better than the story telling group in learning collocations. In addition to that, the study by Gallets (2005) supports the notion that both story reading and storytelling can be used as part of an effective program for emerging readers. His finding suggests that storytellers are engaging in an activity that is enjoyable for students, and at the same time it can contribute to the educational process. His finding asserted that story reading and storytelling can both help children learn differently. Children who hear through story telling tend to remember more of the information than they hear from story reading. On the other hand, students who hear through telling stories appear to be more likely to show an understanding of formal elements of story structure. In both groups story reading and storytelling of students displayed a similar shift towards more slight types of understanding story meaning. His study shows the students in the story reading group improved more than the students in the storytelling group on three of five measures.

In addition to that, Isbell, Sobol, Lindauer \& Lowrance (2004) studied the impact of storytelling and reading stories on development of language and comprehension of three and five years old children through the experiential group of storytelling and story reading group. Their findings indicated improvement in both groups. However, the storytelling group have better comprehension which showed through their retelling of heard stories. They also suggest that storytelling need a greater use of the visual imagination than in story reading. They further indicated storytelling as an effective tool for engaging students in listening skills development. Another study by Rivera (2016) who found Storytelling and story reading the tools to enhance reading comprehension. He suggests that English learning and category of Storytelling and story reading help most of the students to write their own productions. Her finding indicates that the use of storytelling for interaction and through listening to classmates the improvement of students' own work productivity. She adds, that by using storytelling students may demonstrate and show progress in comprehension, recalling information, and arrangement of events in the correct order. 
On the other hand, Al-Mansour \& Al-Shorman (20II) found that there is no significant difference exist in students' achievement in terms of storytelling and story reading.

Comparative study on the effect of reading story aloud and storytelling on intermediate EFL learners' listening comprehension was conducted by Hemmati, Gholamrezapour \& Hessamy (2015) their findings indicate that that both Storytelling and story reading aloud groups had positive effects on the students' listening comprehension. However, the exact comparison of these two groups shows Storytelling group better performed than story reading group in posttests. They further suggest that story telling without aid of the printed page helps the storyteller and listener to have more connection. They have found evidence for storytelling as being more effective than reading aloud. The study also found that students who listen to a story they in fact learn ways of listening ability. Furthermore, the study also found out improvement of storytelling on oral skills strategies. Beside this storytelling promote language development and span listening skills.

Thus, the story reading and storytelling have been studied and tested its various effects and much of the studies are conducted on children. The literature above is generally summarized the comparative study done on story reading and storytelling, its effects on students learning and developing aptitude. There was need to study on the effects of storytelling on adult intermediate EFL learners mainly to investigate critical thinking and comprehension effects.

\section{Methodology}

- Participants A total number of 27 intermediate junior Afghan EFL undergraduate students from the English departments of Languages and literature faculty and Education Faculty of Kandahar University have taken part in this study. They shared the same first language Pashtu and Dari and were selected through performance in placement test.

- Research Design and Materials: The study is a quasi-experimental research with one experimental group. An objective test that contained 23 questions for measuring reading comprehension and critical thinking aspects was used as a placement test for selecting samples from the papulation. It was developed from reading book by Mikulecky \& Jeffries (2003). The second instrument was used for pre and posttests to test reading comprehension and critical thinking skills. It had two parts and contained 38 multiple choice questions, 19 for critical thinking and 20 for reading comprehension. The first part aim to test critical thinking skills through 19 multiple choice questions among which 9 were by Watson (1980) for making inference from the given text and I0 were for critical thinking to select best ending taken from Free Practice Critical Thinking Test (n.d). The second part was to test reading comprehension skills which contained passages followed with comprehensions multiple choice questions taken from Test Prep Review (2019). The Reliability of instruments were tested before use through test-retest method of reliability and scores result showed stability over time used. The part of validity was checked for content and construct validity of all questions required for testing critical thinking and reading comprehension dimensions. Besides these instruments, a story collection, A World of Fiction by Marcus (2005) was used to present stories in group of storytelling.

- Procedures: In the first phase of the study, the volunteer junior students of both English departments including Preservice, In-service and Night-shift took part in a placement test inside university campus. Then the qualified subjects who got higher marks were shifted to experimental group that contains 30 students. They took the pretest in stress free environment and attend I0-week sessions of treatment in which the storytelling group listened to stories told by their teacher without providing them stories in hand. There was concern for ethical dimension and also to reduce possible confounding variables that may affected the study outcome, participants were assured about their identity to be kept confidential. Since the participant were given the choice of withdrawing their participation at any time and during tenweek session some of the students withdraw their participations and some did not attend posttests and 27 remained took parts in posttest. After ten-week treatment 90 minutes for week the students who answered the questions of the posttest in equal time provided to each individual in group.

- Data Analyzing Procedure: Both pre and post test score were administrated in Microsoft Excel, SPSS 24 version and Graph pad prism. The result was analyzed for showing percentage, mean and standard deviation. Paired Sample T-test was used to show the significant improvement and difference. The result for all presented in tables and graphs.

\section{Findings}

As mentioned before, the experiential study was conducted in a treatment group of storytelling to find out comparative results on the improvement of critical thinking and reading comprehension. The findings presented based on each research questions and for the questions "What is the effect of storytelling on reading comprehension and critical thinking of EFL students?" The data was collected in order to find the effect of storytelling on improving critical thinking and reading comprehension. 
Table I. Storytelling Pre- and Post-Test Result

\begin{tabular}{|c|c|c|c|c|c|c|}
\hline \multirow[t]{2}{*}{ Number } & \multirow[t]{2}{*}{ Name } & \multirow[t]{2}{*}{ F/Name } & \multicolumn{2}{|c|}{ Critical Thinking } & \multicolumn{2}{|c|}{$\begin{array}{c}\text { Reading } \\
\text { Comprehension }\end{array}$} \\
\hline & & & $\begin{array}{l}\text { Pre- } \\
\text { test }\end{array}$ & $\begin{array}{l}\text { Post- } \\
\text { test }\end{array}$ & Pre-test & Post- test \\
\hline $\mathrm{I}$ & Shamsullah & Gulam Muhidin & 25 & 20 & 0 & 6 \\
\hline 2 & Naeemullah & M.Farooq & 35 & 65 & 16 & 37 \\
\hline 3 & Muhibullah & Mayeengul & 25 & 45 & 27 & 27 \\
\hline 4 & Khudad & Awaz & 30 & 65 & 27 & 37 \\
\hline 5 & Shabmum & Abdul Ghani & 50 & 70 & 32 & 37 \\
\hline 6 & M. Zia & M. Nazeem & 30 & 50 & 27 & 37 \\
\hline 7 & M Deen & Khuridin & 30 & 35 & 6 & 32 \\
\hline 8 & Nooria & M. Aqbaal & 45 & 55 & 27 & 32 \\
\hline 9 & Sayedullah Jan & Gulam Jailani & 35 & 80 & 27 & 74 \\
\hline 10 & Sumia & Qurban Ali & 65 & 75 & 27 & 58 \\
\hline II & Khushal & Abdul Salam & 25 & 30 & 0 & 26 \\
\hline $\mathrm{I} 2$ & Hamidullah & Nida Mohammad & 35 & 35 & 43 & 53 \\
\hline $\mathrm{I3}$ & Wali Mohammad & Gul Mohammad & 30 & 55 & 16 & 26 \\
\hline $\mathrm{I} 4$ & Shamudin & Gulam Muhidin & 0 & I0 & 27 & 16 \\
\hline I5 & Subhanullah & Anargul & I0 & $\mathrm{I} 5$ & 32 & 42 \\
\hline 16 & Mujeburahman & Gulamudin & 40 & 45 & 27 & 32 \\
\hline 17 & Khan Mohammad & Ali Jan & 25 & 35 & 16 & 37 \\
\hline I8 & Hayatullah & M. Esaa & 30 & 25 & II & 42 \\
\hline 19 & Zahir Shah & Sayeed Hakim & 25 & 30 & II & 26.3 \\
\hline 20 & Ahmadullah & Naqeebullah & 55 & 30 & 32 & $2 \mathrm{I}$ \\
\hline $2 \mathrm{I}$ & Farid Ahmad & Mukhtar Ahmad & 25 & 30 & 16 & 26 \\
\hline 22 & Sheer Zamaan & M.Zaman & 45 & 25 & 6 & $2 \mathrm{I}$ \\
\hline 23 & Naseer Ahmad & Shan Gul & 30 & 35 & 16 & $2 \mathrm{I}$ \\
\hline 24 & Ezatullah & Abdul Baqi & 20 & 35 & 27 & 42 \\
\hline 25 & Habiudin & Nasrudin & 35 & 40 & II & 26 \\
\hline 26 & Najeeullah & Akhatar Mohammad & $\mathrm{I} 5$ & 30 & 32 & 47 \\
\hline 27 & Shafiqullah & Malang & 30 & 25 & 27 & 26 \\
\hline
\end{tabular}

TableI above indicates pre and post results of the participants in storytelling group for reading comprehension and critical thinking aspect and the mean scores of them. The group of storytelling contains 27 students who attended I0 weeks' course designed to find out wither story reading help in improving critical thinking and reading comprehension. Their result in pre and posttest indicates majority of the students who participated in storytelling course their test scores have increased in critical thinking and reading comprehension. Among them only few students' marks have either decreased or did not improve. For instance, student one who got $25 \%$ marks in critical thinking pre-test but his marks in posttest are $20 \%$ on the other hand his score in posttest has increased in reading comprehension from $0 \%$ to $6 \%$ Also student three who got $27 \%$ marks in pre-test of reading comprehension section but his posttest contains $26 \%$ on the other hand his post test in critical thinking section increased from $25 \%$ into $45 \%$. In addition to that student 18 who got 30\% marks in pre-test of critical thinking section his posttest decreased 
to $25 \%$ marks yet his marks have improved in reading comprehension section from I I \% into $42 \%$. Similarly, student 20 who got $55 \%$ in critical thinking pre-test his marks deceased into $30 \%$ in posttest. His marks also decreased in reading comprehension into $21 \%$ from $32 \%$. Likewise, student 22 who got $45 \%$ marks in critical thinking pre-test has decreased into $25 \%$ in post but on the other hand his marks improved in reading comprehension section from $6 \%$ into $21 \%$ in reading comprehension section. in addition to that student 27 who got $30 \%$ marks in pre-test of critical thinking his posttest result decreased into $25 \%$ and there is also decrease in his reading comprehension section from $27 \%$ into $26 \%$.

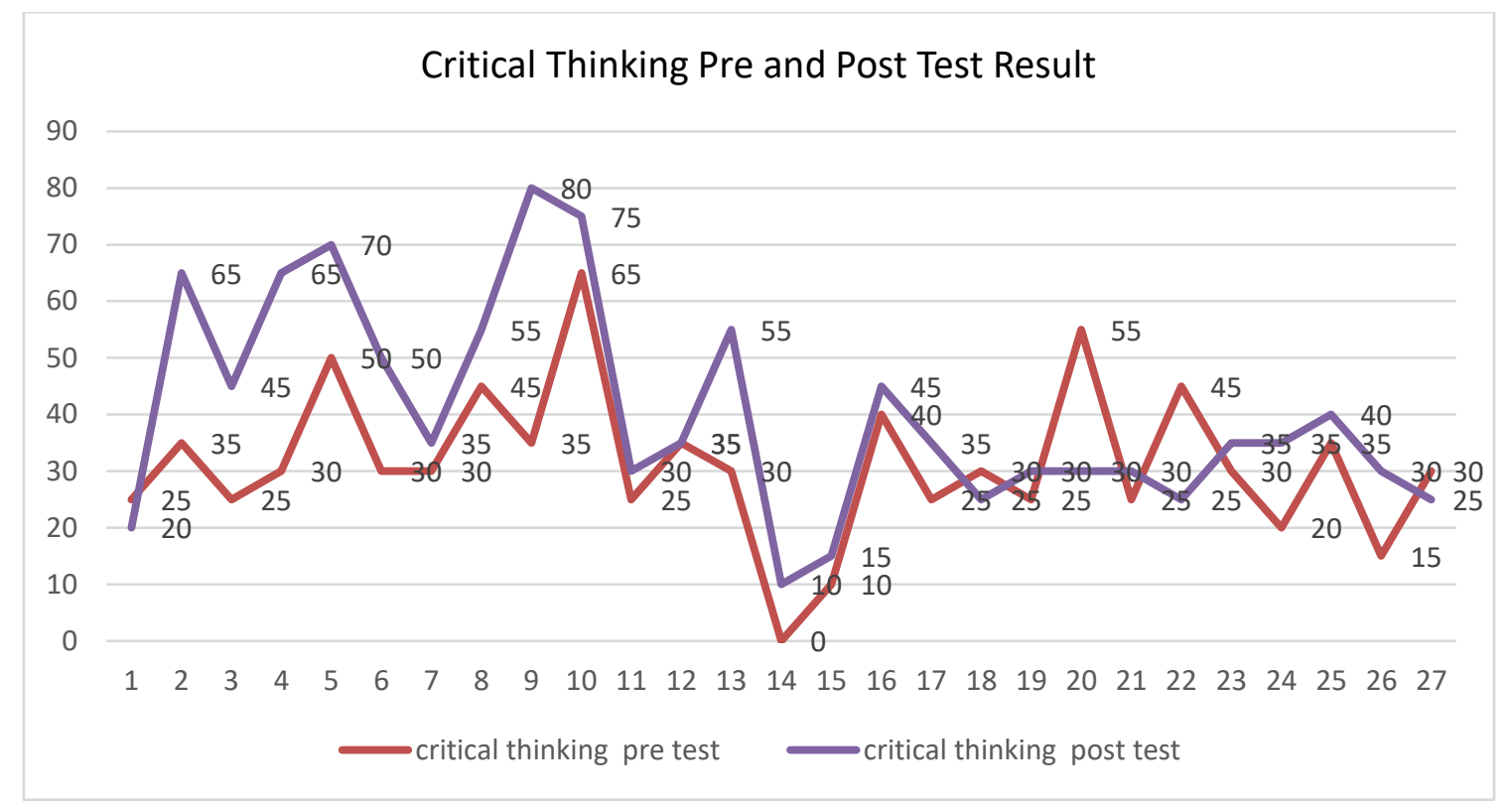

Figure I. Pre-Test and Post-Test Result of Critical Thinking Section in Storytelling group

Figure I above shows pre and post test result of critical thinking section in storytelling group. Orange color shows pretest result while yellow color represents post test result. Among 27 students who participated in ten-week program of storytelling course have improved in posttest of critical only five students' marks decreased rather than increased in posttest which have been highlighted with yellow color in table I.I. Comparing overall majority of students' performance have been improved in posttest of critical thinking section.

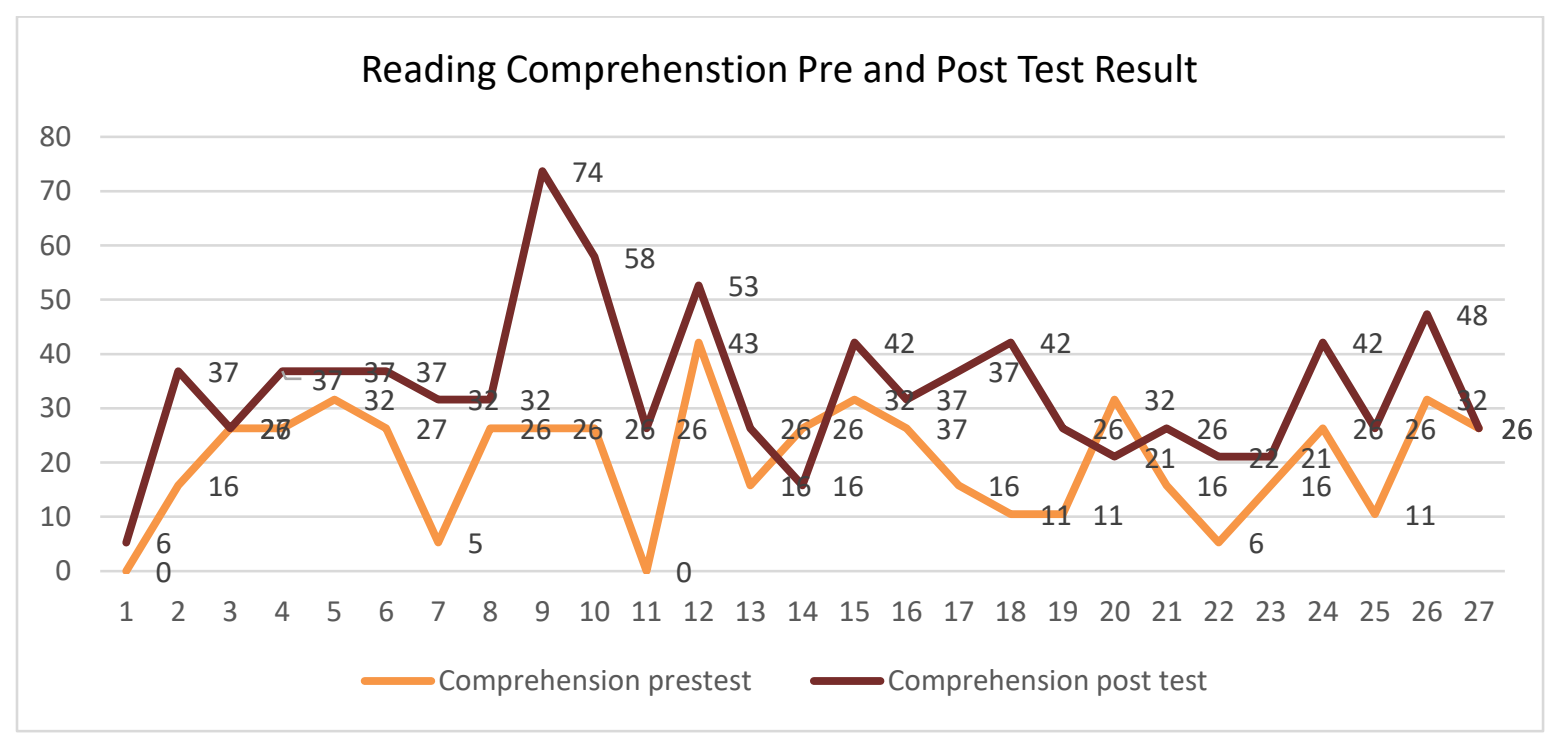

Figure 2. Pre and Post Test Result of Reading Comprehension Section in Storytelling group 
Figure 2 above shows pre and post test result of reading comprehension section in storytelling group. Green line represents pretest result while the maroon color represents post test result. Among 27 students, only three students got lowered marks in post than pretest. Overall majority of students' marks have been increased in posttest from the marks they got in pre-test.

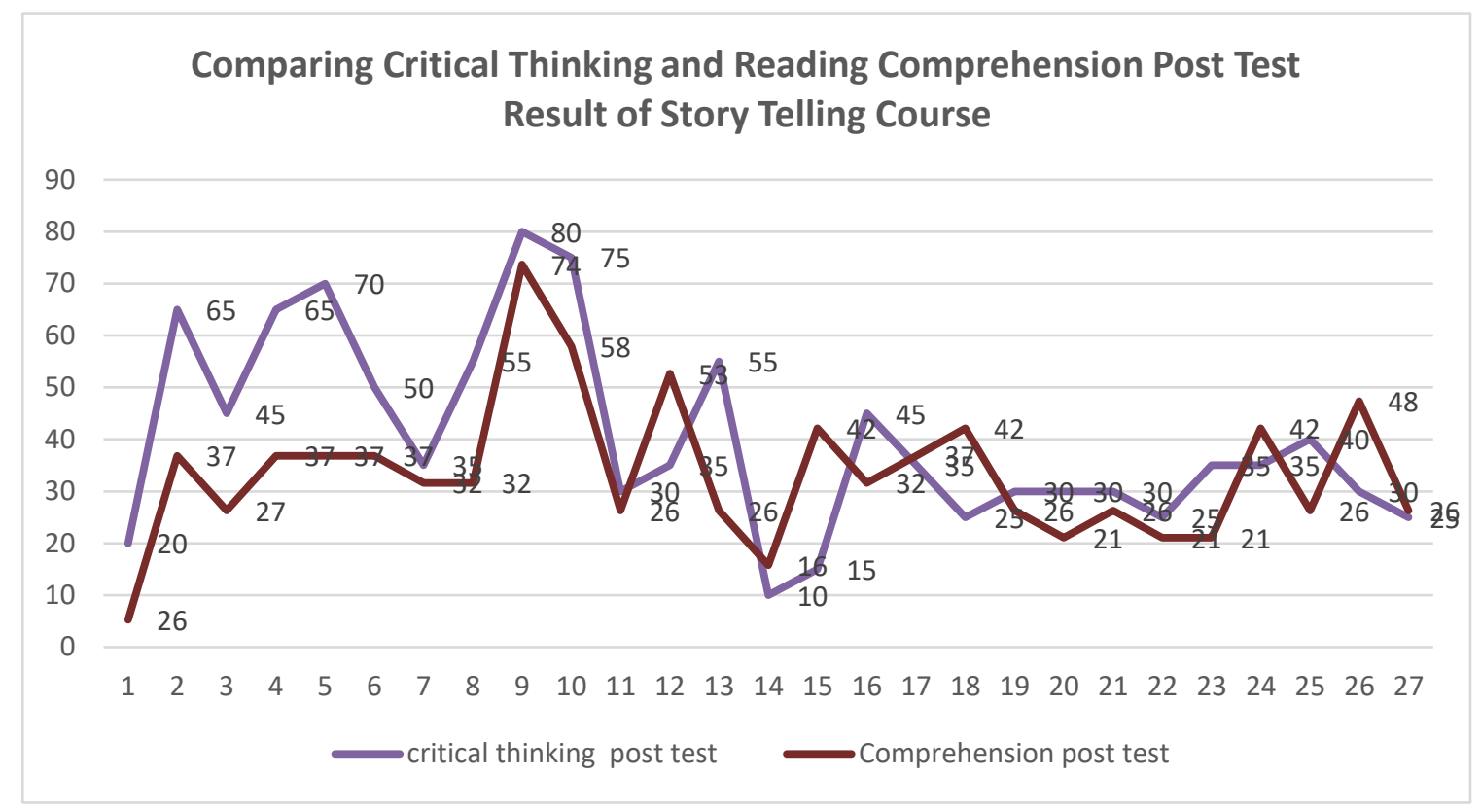

Figure 3. Comparison of Post Test Results of Critical Thinking and Reading comprehension in Storytelling group:

Figure 3 above represents posttests result of reading comprehension and critical thinking sections of storytelling group. Yellow color indicates critical thinking posttest while maroon colors shows reading comprehension post test result. Students who participated in story telling group, their result shows they have improved in reading comprehension as well in critical thinking section while their results also indicate they have got higher scores in critical thinking section than reading comprehension section.

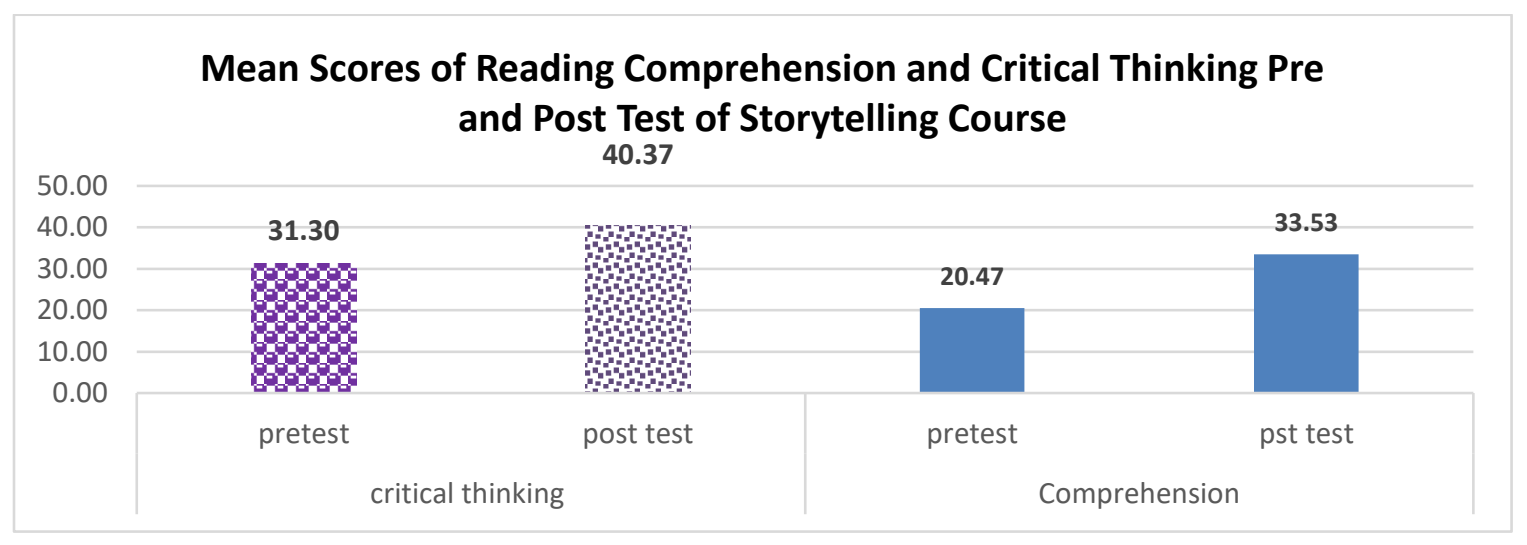

Figure 4. Mean Scores of Reading Comprehension and Critical Thinking Pre and Post Test in Storytelling Group

Figure 4. above indicates mean scores of reading comprehension and critical thinking pre and posttest of storytelling group. Result shows students who participated in story telling group their mean score in pretest of critical thinking section is 3 Imean score while their mean score has improved to 40 mean score. On the other hand, they have got the mean score 20 mean score in pretest of reading comprehension section which have been increased into 34 mean score in posttest. The means scores result shows there is improvement in posttests from pre-tests in both areas of critical thinking and reading comprehension. 
However, the result also indicates there is more improvement in reading comprehension aspects of students who participated in story telling course than reading comprehension.

Table 2. Mean and Standard Deviation of Story Telling Group for Pre and Post Result in Critical Thinking and Reading Comprehension

\begin{tabular}{|c|c|c|c|c|c|}
\hline \multicolumn{6}{|c|}{ Statistics } \\
\hline & & $\begin{array}{c}\text { Critical Thinking } \\
\text { in Storytelling } \\
\text { Pre-test }\end{array}$ & $\begin{array}{c}\text { Critical Thinking } \\
\text { in Storytelling } \\
\text { Post-test }\end{array}$ & $\begin{array}{c}\text { Reading } \\
\text { Comprehension in } \\
\text { Storytelling Pre-test }\end{array}$ & $\begin{array}{l}\text { Reading Comprehension } \\
\text { in Storytelling Post-test }\end{array}$ \\
\hline \multirow[t]{4}{*}{$\mathrm{N}$} & Valid & 27 & 27 & 27 & 27 \\
\hline & Missing & 0 & 0 & 0 & 0 \\
\hline & Mean & 31.2963 & 40.3704 & 20.4700 & 33.5244 \\
\hline & Deviation & I3.3440I & 18.39345 & 10.76121 & $\mathrm{I} 3.856$ \\
\hline
\end{tabular}

Table 2 above indicates mean and standard deviation of storytelling group for pre and post result of critical thinking and reading comprehension. $M$ represent the mean score while SD shows standard deviation. Result indicates students in Storytelling group in Pre-test of critical thinking section, they got M score 3I.3 and SD I3.3 and its increased into M score 40.4 and SD I8.4 in post-test. However, in reading comprehension pre-test students got M score 20.5 and SD I0.8 which have been increased into $\mathrm{M}$ score 33.6 and SDI3.9.

\section{Means and S.D}

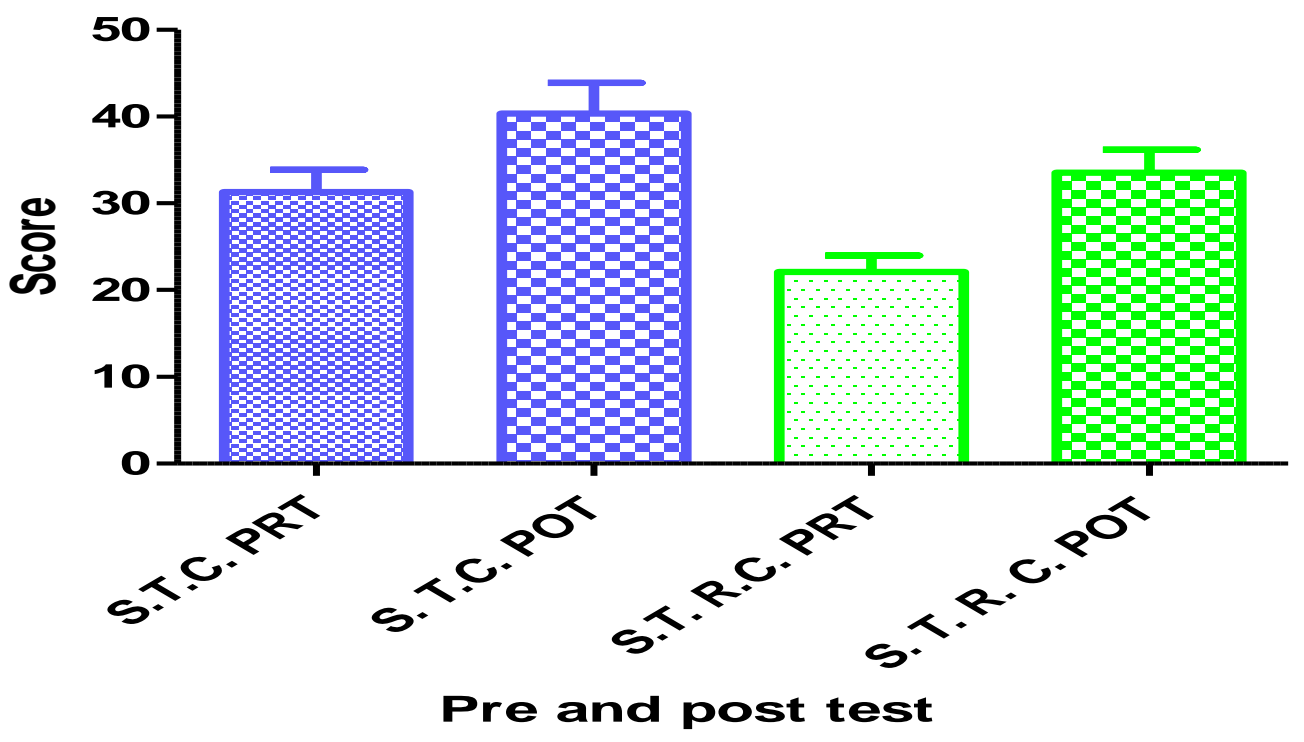

Figure 5. Mean and Standard Deviation of Pre and Post Test Result of Story Telling Course for Its Critical Thinking and Reading Comprehension Section

Figure 5 above represents standard deviation of pre and post test result of storytelling course for its critical chinking and reading comprehension section. The abbreviation S.T. stand for storytelling, C for critical thinking PRT stand for pre-test, POT for posttest, $\mathrm{RC}$ for reading comprehension. The blue color on the lift indicates mean score and SD of pretest result of critical thinking section in storytelling course while blue on the right represent $\mathrm{M}$ and SD of post-test result. On the green on the lift represent pre-test result of reading comprehension and storytelling group while green on the right represent $\mathrm{M}$ and SD for the post-test of reading comprehension. 
Table 3. T-Test Mean Comparison of Reading Comprehension Pre and Post Test Result in storytelling course: Paired Samples Statistics

\begin{tabular}{|c|c|c|c|c|c|c|}
\hline & & & Mean & $\mathrm{N}$ & Std. Deviation & Std. Error Mean \\
\hline \multirow[t]{2}{*}{ Pair I } & $\begin{array}{l}\text { Reading } \\
\text { Pre-test }\end{array}$ & Comprehension & 20.4700 & 27 & $\mathrm{I} 0.76 \mathrm{I} 2 \mathrm{I}$ & 2.07100 \\
\hline & $\begin{array}{l}\text { Reading } \\
\text { Post-test }\end{array}$ & Comprehension & 33.5244 & 27 & 13.85573 & 2.66654 \\
\hline \multicolumn{7}{|c|}{ Paired Samples Correlations } \\
\hline & & & $\mathrm{N}$ & Correlation & & Sig. \\
\hline $\begin{array}{l}\text { Pair } \\
\text { I }\end{array}$ & $\begin{array}{l}\text { Reading } \\
\text { Pre-test } \\
\text { Compreh }\end{array}$ & $\begin{array}{l}\text { Comprehension } \\
\& \quad \text { Reading } \\
\text { asion Post-test in }\end{array}$ & 27 & .494 & & .009 \\
\hline
\end{tabular}

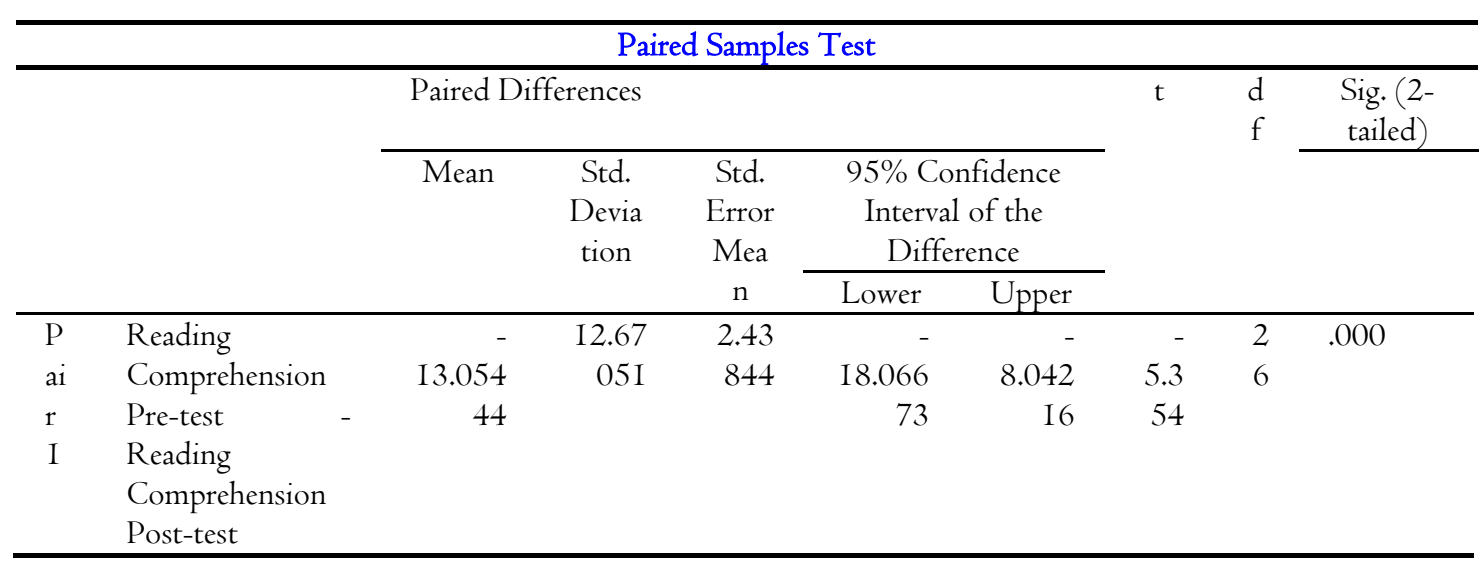

Table 3. above indicates T-Test Mean Comparison of Reading Comprehension Pre and Post Test Result in storytelling group. Students at pretest of reading comprehension got the mean score of 20.5 and they got the mean score 33.6 in posttest which shows the difference -I3.0 mean score between pre and posttest and P value .000 shows the significant improvement in students' posttest.

Table 4. Paired T-Test Mean Compression for Critical Thinking

\begin{tabular}{|c|c|c|c|c|c|}
\hline \multicolumn{6}{|c|}{ Paired Samples Statistics } \\
\hline & & Mean & $\mathrm{N}$ & Std. Deviation & Std. Error Mean \\
\hline \multirow[t]{2}{*}{ Pair I } & Critical Thinking Pre-test & 31.296 & 27 & I3.3440I & 2.56806 \\
\hline & Critical Thinking Post-test & $\begin{array}{r}40.370 \\
4\end{array}$ & 27 & I8.39345 & 3.53982 \\
\hline \multicolumn{6}{|c|}{ Paired Samples Correlations } \\
\hline & & & $\mathrm{N}$ & Correlation & Sig. \\
\hline Pair I & $\begin{array}{l}\text { Critical Thinking Pre- } \\
\text { Thinking Post-test }\end{array}$ & \& Critical & & .590 & .001 \\
\hline
\end{tabular}


Table 4 above indicates paired T-Test mean compression of storytelling for critical thinking. Students in storytelling group in pretest of critical thinking got the mean score 31.3, however they got in posttest 33.6 and the difference between pre and posttest mean is -9.0 the $\mathrm{P}$ - value is .004 a significant improvement in posttest of storytelling group.

Table 5. Paired T-Test Mean Compression of Posttests of Critical Thinking and Reading Comprehension

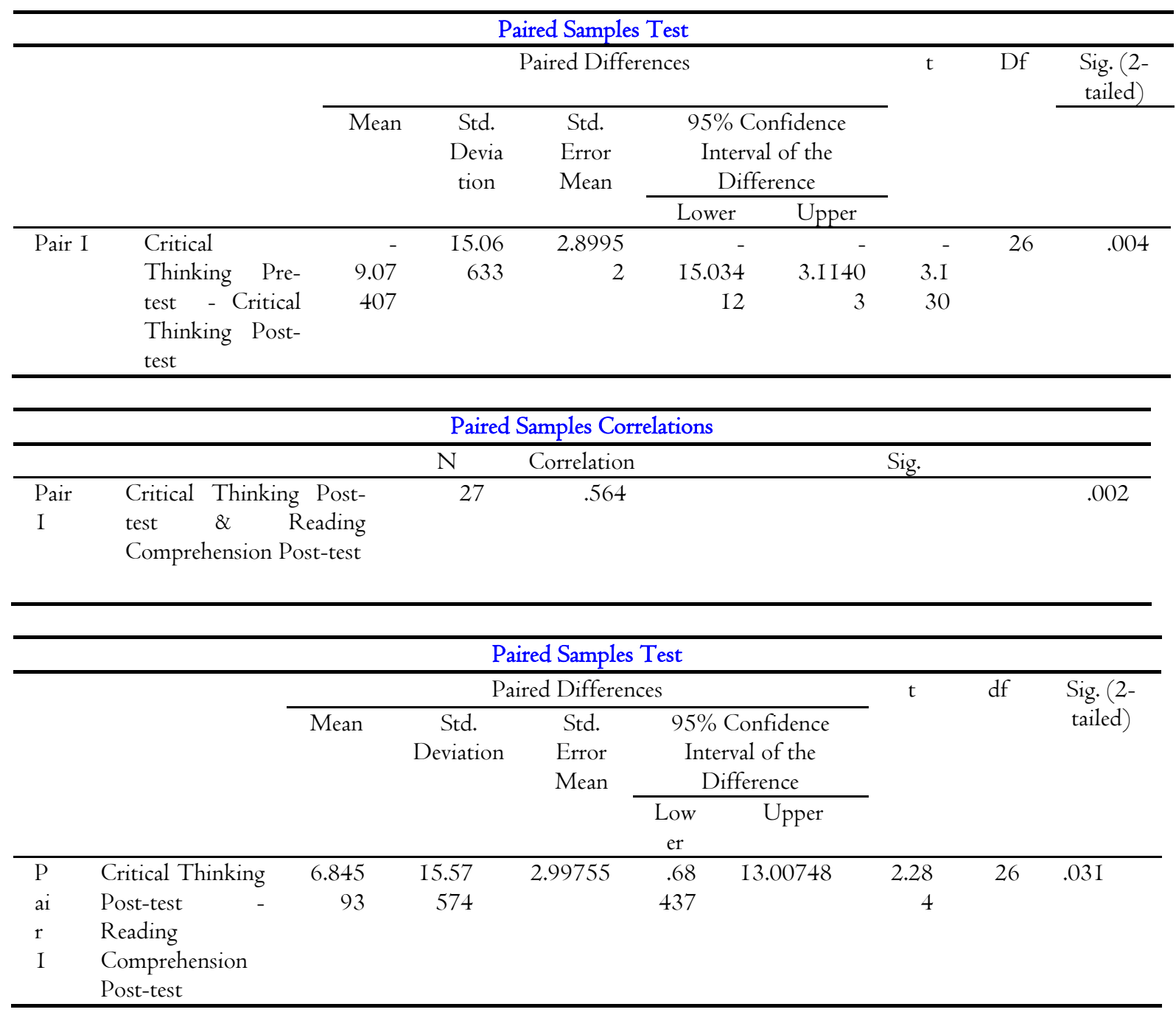

Table 5 Paired T-Test Mean comparison of posttests of critical thinking and reading comprehension. Students in story telling group in critical thinking posttest got the mean score 40.4 while they got 33.5 mean score and there is 6.9 mean difference that indicated by P-value.03I less different between posttests of reading comprehension and critical thinking in storytelling course.

\section{Discussion}

Result of the current study shows that there is improvement in reading comprehension and critical thinking of the students in storytelling. However, participants' in reading comprehension improved from 20 mean score into 34. These findings are supported by Phillips (1999); Ta'amneh (2018); Goudvis \& Harvey (2000) who wrote that storytelling improve reading comprehension. The critical thinking aspect of students is also improved from $3 \mathrm{I}$ mean score into 40 mean score. This finding is supported by Belet, \& Dala (2010); Chan (2019); Palmer, Harshbarger \& Koch (200I) who assert that storytelling improves critical thinking.

This study is also aligned with Rivera Pinzón (2016) who found out that storytelling and story reading as the tools to enhance reading comprehension. Though there is improvement in the areas of critical thinking and reading comprehension, there is over all mean improvement of $\mathrm{I} 3$ from pretest in critical thinking section in. have improved I3.0. Result of descriptive means shows improvement is higher in reading comprehension. 
Thus, the result further needed to be tested through Paired Sample-Test for mean comparison in order to find out the existed difference and improvement is significant or not. It was found out there was significant improvements which indicated with $\mathrm{P}$ value .000 in the area of reading comprehension among pre and posttest and also in critical thinking areas with $\mathrm{P}$ value .004 in pre and posttest respectively. Paired Samples T-Test was used to find out with in the group difference in term of reading comprehension and critical thinking posttest comparison and the result indicated that, there was $\mathrm{P}$ value.03I that indicated less significant difference existed in critical thinking post-test and reading comprehension post-test.

It is also supporting the findings by Gallets (2005) who find that Children who hear through story telling tend to remember more of the information. The similar findings reveled by (Isbell, et at., 2004) as improvement in comprehension aspect in both groups yet the storytelling group have better comprehension which showed through their retelling of heard stories.

\section{Conclusion and Recommendation}

Storytelling is playing a significant role in literacy development and its role in language development is vital. It empowers reading comprehension and critical thinking which is important for students in any major and especially for EFL students. It is important for individual who want to learn English he or she should think in English and thinking is improved through storytelling techniques. Stories contains elements as (inferences, suspense, exploring themes, genera, symbols thinking and literary terms) lead learners to think for the meaning and comprehension. Thus, thinking for these elements increase critical thinking. It's through critical thinking one can improve language and presentation skills. Thinking clearly and systematically can advance the way we express our ideas. It helps us in learning how to scrutinize the rational structure of texts and through critical thinking one can develop his/her comprehension aptitudes. A critical thinker has the self-awareness of logic to recognize the difference between rational views and careful expression.

The findings of this study show that there is significant improvement in areas of critical thinking and reading comprehension through storytelling. However, the students' achievements vary in terms of critical thinking and reading comprehension. That is, improvement is higher in reading comprehension which indicates $9 \%$ improvement. EFL Departments should include Storytelling in their curriculum which helps students in literacy development for it is plying important role in language skills development in various areas. The critical thinking and reading comprehension aspect have been proved through the current study and its impacts on development of writing, listening comprehension vocabulary building can be acknowledged from previous studies discussed in literature review.

\section{References}

Abrahamson, C. E. (1998). Storytelling as a pedagogical tool in higher education. Education, I I8(3), 440-452.

Alkaaf, F., \& Al-Bulushi, A. (2017). Tell and Write, the Effect of Storytelling Strategy for Developing Story Writing Skills among Grade Seven Learners. Open Journal of Modern Linguistics, 7(02), I I9.

Al-Mansour, N. S., \& Al-Shorman, R. E. A. (20II). The effect of teacher's storytelling aloud on the reading comprehension of Saudi elementary stage students. Journal of King Saud University-Languages and Translation, 23(2), 69-76.

Belet, S. D., \& Dala, S. (2010). The use of storytelling to develop the primary school students' critical reading skill: the primary education pre-service teachers' opinions. Procedia-Social and Behavioral Sciences, 9, I830-I834.

Chan, C. (2019). Using digital storytelling to facilitate critical thinking disposition in youth civic engagement: A randomized control trial. Children and Youth Services Review, I07, I04522.

Craig, S., Hull, K., Haggart A., \& Crowder, E. (200I). Storytelling: Addressing the Literacy Needs of Diverse Learners. Teaching $\begin{array}{lllll}\text { Exceptional Children. } & 43 & \text { 46-5I. } & \text { Retrieved }\end{array}$ fromhttps://journals.sagepub.com/doi/abs/IO.I I77/004005990I03300507?journalCode=tcxa

Cremin, T., Mottram, M., Collins, F., Powell, S., \& Safford, K. (2009). Teachers as readers: building communities of readers. Literacy, 43(I), II-I9.

Dugan, J. (1997). Transactional literature discussions: Engaging students in the appreciation and understanding of literature. The Reading Teacher, 5I(2), 86-96.

Ellis, G., \& Brewster, J. (20I4). Tell it again!: the storytelling handbook for primary english language teachers. London: British Council. Penguin Books.

Free Practice Critical Thinking Test. (n.d). Retrieved October I0, 2018, from https://www.testpartnership.com/free/critical/I/

Furlong , R. (2013, February) 2I st Century English Education Remixing the Teaching of English for a New Generation retrieved 28,Junavery, 2019, from http://2Istcenturyenglisheducation.blogspot.com/2013/02/oral-narratives-and-storytelling-in.html

Gallets, M. P. (2005). Storytelling and Story Reading: A Comparison of Effects on Children's Memory and Story

Comprehension. Retrieved from https://dc.etsu.edu/cgi/viewcontent.cgi?article=2I80\&context=etd

Goudvis, A., \& Harvey, S. (2000). Strategies that work: Teaching comprehension to enhance understanding. York, ME: Stenhouse. 
Haven, K. F., \& Ducey, M. (2007). Crash course in storytelling. Boston: Greenwood Publishing Group.

Haycock, K., \& Huang, S. (200I). Are today's high school graduates ready? A closer look at college students: Self-efficacy and goal orientation. Journal of Advanced Academics, I8, 454-476.

Hemmati, F., Gholamrezapour, Z., \& Hessamy, G. (2015). The effect of teachers' storytelling and reading story aloud on the listening comprehension of Iranian EFL learners. Theory and Practice in Language Studies, 5(7), I482-I488.

Isbell, R., Sobol, J., Lindauer, L., \& Lowrance, A. (2004). The effects of storytelling and story reading on the oral language complexity and story comprehension of young children. Early Childhood Education Journal, 32 (3), I57-I63.

Marcus, S. (Ed.). (2005). $2^{\text {nd }}$ edn. A world of fiction: Twenty timeless short stories. Boston: Allyn \& Bacon.

Mello, R. (200I). Building bridges: How storytelling influences teacher and student relationships. In Proceedings, storytelling in the Americas conference. St. Catherine, ON: Brooks University Press ERIC Document Reproduction Service No. ED457088) retrieved from https://files.eric.ed.gov/fulltext/ED457088.pdf

Mikulecky, B. S., \& Jeffries, L. (2003). $2^{\text {nd }}$ edn. More reading power. New York: Longman Pearson.

Miller, S., \& Pennycuff, L. (2008). The power of story: Using storytelling to improve literacy learning. Journal of CrossDisciplinary Perspectives in Education, I(I), 36-43.

National Council of Teachers of English: Position Statement from the Committee on Storytelling. (I992). Teaching Storytelling. Retrieved June 27, 2019, from http://www2.ncte.org/statement/teachingstorytelling/

Palmer, B. C., Harshbarger, S. J., \& Koch, C. A. (200I). Storytelling as a constructivist model for developing language and literacy. Journal of Poetry Therapy, I4(4), I99-212.

Phillips, L. (1999). The role of storytelling in early literacy development. (ERIC Document Reproduction Service No. ED444147). Retrieved from https://files.eric.ed.gov/fulltext/ED444I47.pdf

Reading Comprehension Practice Test I - Test Prep Review. (2019) Retrieved October I0, 20I8, from https://www.testprepreview.com/modules/readingI.htm

Remenyi, D. (2005). Tell me a Story-A way to Knowledge. The Electronic Journal of Business Research Methodology, 3(2), I33-I40.

Rivera Pinzón, M. X. (2016). Storytelling \& Story-Reading: A way to Enhance EFL Students' Literacies.(Master's Thesis) Retrieved from University Distrital Francisco José de Calda.(Access No. 19. 1988-177).

Saadati, F., Tarmizi, R. A., \& Bayat, S. (2010). Assessing critical thinking of postgraduate students. Procedia-Social and Behavioral Sciences, 8, 543-548.

Sahibzada, J., Saeedi, K.H., \& Hussaini, M. A.(2018) The Causes of English Language and Literature Students' Poor English Skills at Kandahar University. International Journal for Innovative Research in Multidisciplinary Field, 4(IO), I-I4.

Sanaeifar, S. H. (2018). The Effect of Word Exposure Frequency through Story Reading and Story Listening on Learning Collocations, Language Education Studies, 4(4), I-8.

Soleimani, H., \& Akbari, M. (2013). The effect of storytelling on children's learning English vocabulary: A case in Iran. International Research Journal of Applied and Basic Sciences, 4(II), 4005-40I4.

Straková, Z. (20I I). Using Storytelling with Intensive Reading in Adult Classes (Doctoral dissertation). Retrieved from University Masarykova). (Access No. I04497).

Ta'amneh, M. I. (2018, September) The Effect of Using Storytelling on Developing Saudi EFL University Students' Reading Comprehension. Journal of Education and Practice, 9, 80-87.

Tovani, C. (2000). I read it, but I don't get it: Comprehension strategies for adolescent readers. Portland: Stenhouse Publishers.

Watson, G. (1980). Watson-Glaser critical thinking appraisal. San Antonio, TX: Psychological Corporation. Retrieved October I0, 2018, from https://www.assessmentday.co.uk/free/watson glaser/freetestI/Inferences/index.php?extratime=999999999999999999999 


\section{Acknowledgement}

This article involves many peoples' efforts and assistance, so it would be time take this chance to express our deep gratitude to them. we would give our gratitude to all participants who actively contributed through their involvement in teen week session and provide data for findings of this research. To the advisor Yarmommad Bahrami Ahmad Zai for his efforts and supervising the writing of this project with great love and patience which enabled us to complete this research. we feel that his enlightening suggestions, incisive comments and constructive criticism have contributed greatly to the completion of this research work. To have worked with him, proved to be a highly rewarding experience for us. we owe him special thanks for the time and trouble he had to go over the drafts. A vote of thanks to Assistant professor Khadim Hussien Saedi for his patient guidance of scholarly touch, Associates professor Dr. Najeebullah Rafiqi and Associates Professor Dr. Zargoon Tareen for their helps in data analysis. This article could never have reached its present form without their guidance. In short, the completion of the project should be attributed to joint efforts of thereof.

\section{Copyrights}

Copyright for this article is retained by the author(s), with first publication rights granted to the journal. This is an open-access article distributed under the terms and conditions of the Creative Commons Attribution license (http://creativecommons.org/licenses/by/4.0/). 